\title{
移動損失基準による地域施設密度と人口密度の理論的関係に関する研究

\author{
THEORETICAL RELATIONSHIP BETWEEN FACILITY DENSITY \\ AND POPULATION DENSITY DETERMINED \\ BY MINIMIZING TRAVEL COST OF USERS
}

\author{
鈴木 勉* \\ Tsutomu SUZUKI
}

\begin{abstract}
This paper derives a precise form of the relationship between facility density and population density from the general assumption that facilities locations are determined in such a way as to minimize the travel distance of users. Models generally lead to an exponential function with an exponent, and especially, the 'minisum' standard derives that facility density is proportional to population density raised to the twothirds power. After the application of this theoretical relationship to empirical relations, it is found that some public facilities confirm the result. The exponent of public facilities tends to be smaller than that of retail stores.
\end{abstract}

Keywords: population density, facility density, travel cost, location-allocation model

人口密度, 施設密度, 移動損失, 立地配分モデル

\section{1. はじめに}

地域公共施設の望ましい整備水準は，都市・地域計画における古 典的ともいえる研究課題である. 整備水準を決定する要因としては, 人口とその年䖋構成，人口変動，産業構造，施設利用の季節的・時 間的変動などが考えられ，より現実的には，敷地条件，交通基盤整 備状況，住民の要望，財政状況なども重要な決定要因となることも 多い. しかし、この内, 最も基本的で重要な要因は人口であろう. 施設の配置を評価する際には，サービス圈人口そのものや，施設ま での距離，施設の容量など人口分布に影響される指標が頻繁に用い られる．特に，生活上必要性が高く，公共性の高いサービスを提供 する施設については, 人口が最も基本的で重要な決定要因といえる.

例えば，学校や公園等の公共施設の充足度を論じる際，しばしば 人口当たりの施設数という指標が用いられる．例えば，一般的に， 小学校については人口およそ 1 万人当たりに 1 校, 中学校について はおよそ 2 万人当たりに 1 校が設置の目安とされている. 病院・診 療所についても，重度の患者を受け入れる第三次指定医療機関はお よそ 100 万人当たり 1 施設といった設置基淮が設けられている.

勿論, 施設のもつ機能によっては, 施設配置の評価尺度は異なる. 施設計画論によれば，施設配置の評価指標としては，一般に，施設 機能に応じて，表 1 に示すような様々なものが考えられるとされて
いる(柏原 $\left.(1991)^{12)}\right)$ 。ところが,こうした評価尺度から導かれる理 論的な臤置基準を議論した研究例は，思いの外少ない．現実には人 口密度の違いが人口当たり施設数やその基準にも影稫を及ぼしてお り，人口の広がりも加味した施設基準に関する議論が必要である.

本諭文は，評価尺度から理論的に施設数と人口の関俰を明らかに し，マクロな関保として施設密度（単位面積当たり施設数）が人口 密度（単位面稓当たり人口; 但し, 施設利用人口は人口に比例する と考える）の果乗に比例するという一般式を導くと同時に，施設数 のデータから理論的関係を検証するための実証分析を行うことを目 的とする.

本論文では，表 1 の評価指標のうち，移動損失指標である平均利 用距離と最大利用距離に着目し，それぞれを最小にする施設眍置を 考える．前者は，施設利用者の施設までの移動コストの平均（需要 が所与の場合は総和と同義）を最小化することを目的とするもので ありここの評価基準を minisum 基準と呼ぶことにする（median 問題 に対応)。この基準は，利便性を重視する施設を中心に広範に適用 される.また後者は，施設利用者のうち施設まで最も移動コストの 大きい人のそれ（移動コストの最大値）を最小化することを目的と するものであり,この評価基準を minimax 基準と呼ぶことにする (center 問題に対応)．この基準は，祭急性を重視する施設等に適用 
される.また，前述のように，その地域の人口に比例して兒四する

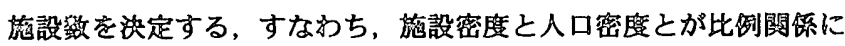

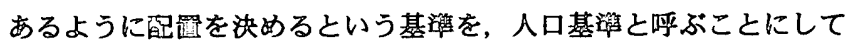
おく.

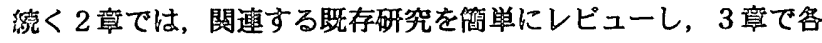

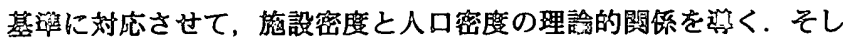

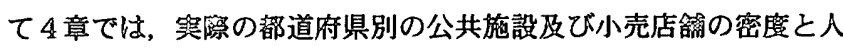

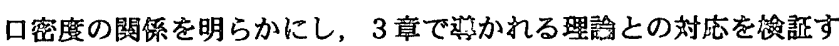

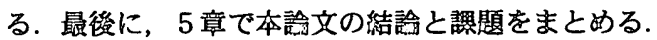

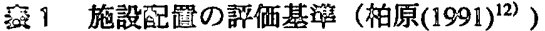

\begin{tabular}{|c|c|c|}
\hline & 分頻 & 指賷 \\
\hline (1) & 利用者票指礿 & 総利用者效 \\
\hline \multirow[t]{3}{*}{ (2) } & \multirow[t]{3}{*}{ 移锄損失指熛 } & 平均移動距雎 \\
\hline & & 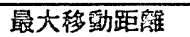 \\
\hline & & 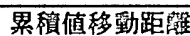 \\
\hline \multirow[t]{3}{*}{ (3) } & \multirow[t]{3}{*}{ 满足性指標 } & 满足图人口 \\
\hline & & 満足者勧 \\
\hline & & 画複图人口 \\
\hline \multirow[t]{5}{*}{ (4) } & \multirow[t]{5}{*}{ 平等性指棒 } & 施設間格差歼 \\
\hline & & 地域間楁差率 \\
\hline & & 最小地域利用率 \\
\hline & & 最小施設利用率 \\
\hline & & 施設钽 \\
\hline
\end{tabular}

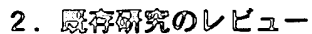

人口密度が高い地域恬ど施設密度も高い，あるいは，高くすべき であるということは，一般に当然のこととして理僻されているか，

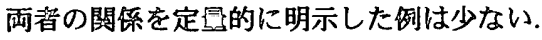

施設配置を浔える上で最も基本的な median 問題を封魚としたも のでは, 立地配分モデルからのアプローチによって, Iri et al. (1984) ${ }^{10)}$

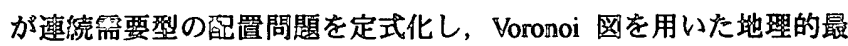
適化手法によって解を求虬ている，尰続简要型モデルを用いること により，一㮞な人口分布の他に, Tanner-Sherram 分布, Newling 分布

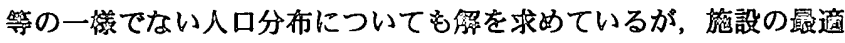

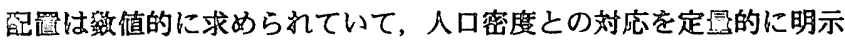
してはいない。一泜には, median 問題を损う研究の多くがネットワ 一ク空間での定式化を行っているが，ネットワーク空間上では施設 分布と人口分布の関俰を明磪に詥じることは图筑である.

施設配置問題としてではなく，独自のアプローチによる研究とし て, Palmer (1973) ${ }^{17}$ が昆適なサーピス地点密度を最短距らの理湓か 5. Stephan $(1972,1977,1988)^{222324)}$, Stephan and McMullin $(1981)^{26)}$ が 自治佮などの領域分割の最通な学位を時間最小化の理詅から， Gusein-Zade (1982a，b，1993)

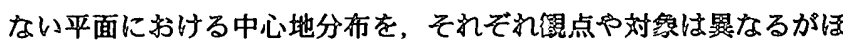

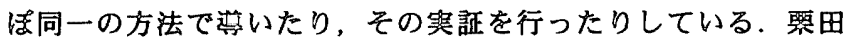

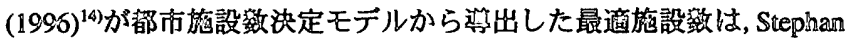

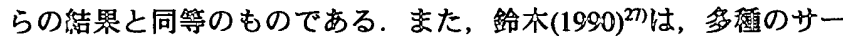

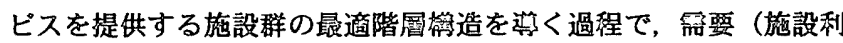

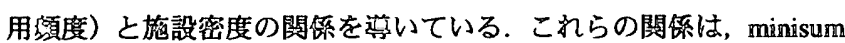
基潐における最適施設密度と共通の染組みで諳詥できるものであり， 本誝文ではこれらの研究のエッセンスを施設密度理諭として位罳づ け（Stephanは「規模密度佔説」と呼んだ）, 次章で詳しく嘧詥する.

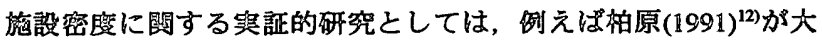
㟲市の公共施設を例に計測しているが，人口密度との閣道には仵れ ていない. 貞広 $(1992,1998)^{191200}$ は，小売店硧を対鱼に人口分布との

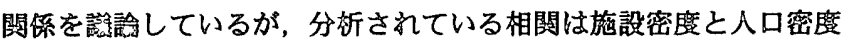
の比例閶係に留きっている. 本研究では，4望で公共施設と小売店

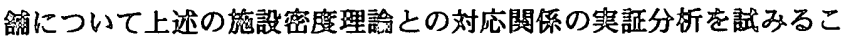
とにする。

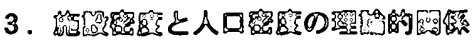 \\ (1) 前提}

図 1 のように，ある地域に人口（図中○）が分布し，そこにサー ビスを提供する点的施設（図中门）を兒置することを考える．人口， 施設就とも十分大きいとし，それらの分布は平面上のなめらかな逴

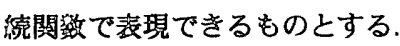

Stephan (1977) 23) と同椂の以下の 4 つの伍定をふく.

(1) 全人口（あるいは地点に能らない一定割合の人口）が施設を利 用し，羁近嚾の施設を蒸択する.

(2) 施設利用㥧噔は，利用替から施設までの距后に俍存しない.

(3) 移钧コストは，距压に比例する.

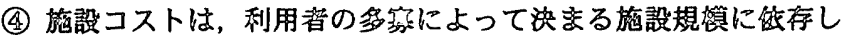
ない. したがって, 棇施設错が一定の場合, 施設コストは定铚とし て哭梘でをる.

(1)の仮定から，施設の圈域は図 1 の哭線で示されるような Voronoi 領瀻となる。一没には施設利用欧は施設からの距源に従って低下す るという閶係にあり，上記の作定は满たされないが，近距にの利用 者が多い地域施設では妥当であると考えられる.

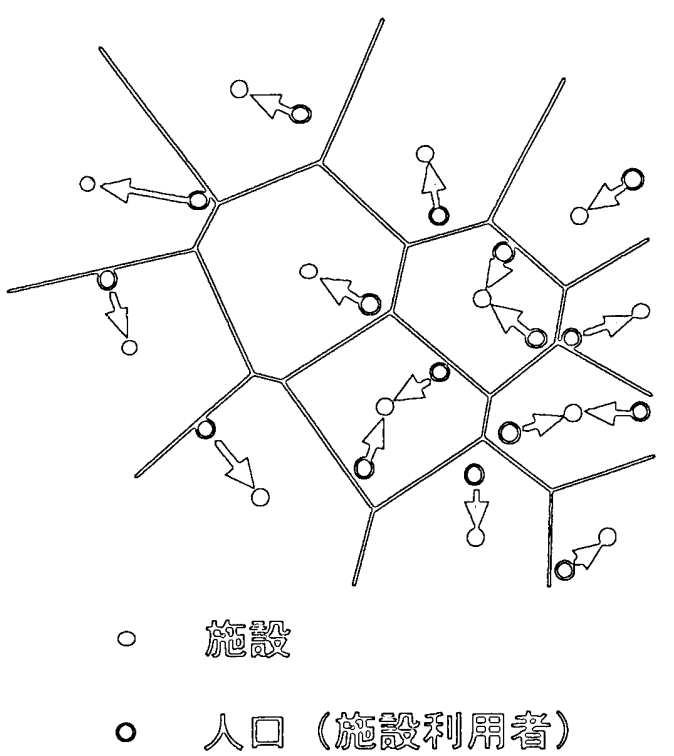

圈 『施設の立地と圈域

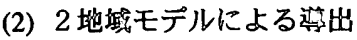

(a) minisum 基準での施設密度

図 2 に示すように，2つの等程の平面領域 $\mathrm{A}, \mathbb{B}$ があり，それぞ れに施設を立地させることを考える. それぞれの人口密度を $p_{A}, p_{B}$ ， 施設密噔を $n_{A}, n_{B}$ とし，いずれも各領域内で一棌であるとする，総

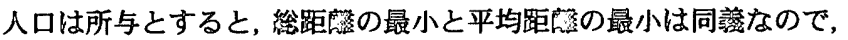


いま, 両地域の施設密度の和 $n=n_{A}+n_{B}$ は一定（総施設数一定と同じ） であるとした場合に, 両地域における施設までの平均距離 $\bar{d}$ を最小 化する施設数の地域配分を考えると，これは以下の問題を解くこと により得られる.

$$
\begin{array}{ll}
\min _{n_{A}, n_{B}} & \bar{d}=\frac{p_{A} d_{A}+p_{B} d_{B}}{p_{A}+p_{B}}, \\
\text { s.t. } & n_{A}+n_{B}=n .
\end{array}
$$

但し， $d_{A}, d_{B}$ はそれぞれ領域 $\mathrm{A}, \mathrm{B}$ での施設までの平均距離であり， 仮定より， $k$ を定数として次式で与えられる.

$$
\left\{\begin{array}{l}
d_{A}=k / \sqrt{n_{A}} \\
d_{B}=k / \sqrt{n_{B}} .
\end{array}\right.
$$

両領域の面積が 1 である場合, 図 1 のように施設の圈域形状がおお よそ正六角形であるとすれは，定数 $k$ は

$$
k=\frac{4+3 \log 3}{24}\left(\frac{2 \sqrt{3}}{3}\right)^{3 / 2} \approx 0.3772
$$

であり，また，近似的に円であるとすれば $k=2 /(3 \sqrt{\pi}) \approx 0.3761$ で ある. (1)式の問題は制的条件付最適化問題であり, Lagrange 未定乗 数法で解くことができる. (2)式を用い， $\lambda$ を末定乗数として Lagrangean は

$$
L=\frac{k}{p}\left(\frac{p_{A}}{\sqrt{n_{A}}}+\frac{p_{B}}{\sqrt{n_{B}}}\right)-\lambda\left(n-n_{A}-n_{B}\right)
$$

となる（但し, $p=p_{A}+p_{B}$ ) ので,一階の条件

$$
\left\{\begin{array}{l}
\frac{\partial L}{\partial n_{A}}=-\frac{k}{2 p} \frac{p_{A}}{n_{A}^{3 / 2}}+\lambda=0 \\
\frac{\partial L}{\partial n_{B}}=-\frac{k}{2 p} \frac{p_{B}}{n_{B}^{3 / 2}}+\lambda=0
\end{array}\right.
$$

を解いて,

$$
\frac{n_{B}}{n_{A}}=\left(\frac{p_{B}}{p_{A}}\right)^{\frac{2}{3}}
$$

という関係が導かれる. すなわち, minisum 基準による最適な施設 密度の比は, 人口密度の比の $2 / 3$ 乗に比例する.

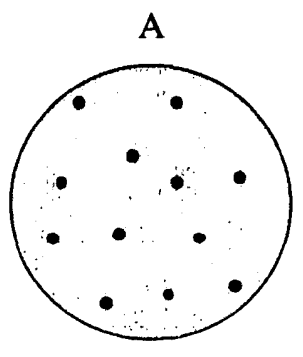

人口密度 $p_{A}$ 施設密度 $n_{A}$

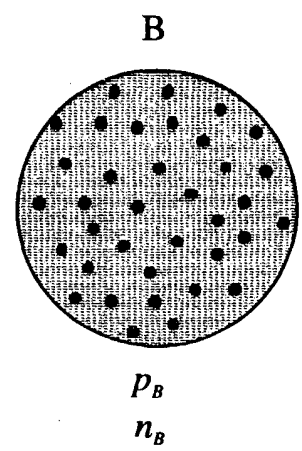

図 22 地域モデル

\section{(b) minimax 基潐での施設密度}

どちらの領域にも人口が僅かとも存在する $\left(p_{A}>0, p_{B}>0\right)$ なら ば, minimax 基準による施設配置は均等配置となり, 施設密度は人 口密度に依存せす，両領域とも同一となる. すなわち，

$$
\frac{n_{B}}{n_{A}}=1
$$

となる.

(c) 人口基潐での施設密度

人口に比例して施設数を決定する人口基準による場合は,

$$
\frac{n_{B}}{n_{A}}=\frac{p_{B}}{p_{A}}
$$

が成り立つ.この考えは，施設の容量が一定であり，施設でのサー ビスレベルを公平にするといった場合に適用される.

また，公共施設でなく小売店舖などの営利施設では，事業採算を 成立させるために一定水準以上の人口を集客することが必要であり， 自由競争による均衡が成り立っていれば，人口基準が基本となると 考えられる. Bunge (1966) $)^{3} に よ り$ 検討された人口密度を可変とした 中心地理諭(Central Place Theory)のための密度変換に関する研究から は，人口基準と同じ結果，すなわち，中心地密度は人口密度に比例

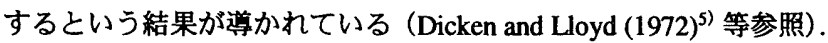

(d) 施設密度と人口密度の理論的関係

以上をまとめると, 配置基淮毎の施設密度と人口密度の関係は, 以下のように整理される．施設密度が人口密度の $\alpha$ 乗に比例すると すれば,

$$
\begin{array}{ll}
\operatorname{minimax} \text { 基準 : } & \alpha=0 \\
\text { minisum 基準 : } & \alpha=2 / 3 \\
\text { 人口 基 準 : } & \alpha=1
\end{array}
$$

ということになる.

(3) 連続モデルによる minisum 基準での関俰の導出

minisum 基潐による(2)(a)の関係については, これと同等のことが, Palmer $(1973)^{17)}$, Gusein-Zade $\left(1982 a\right.$, b) ${ }^{67)}$, Stephan $(1977)^{23)}$, 鉿木 $(1990)^{27)}$ 等によって明らかにされている．これらに共通する本質的 な議論は, 以下のようにまとめられる.

いま，図3のような人口密度が一様でない連続領域 $D$ （連結でな くてもよい）を考える. D 内の地点 $x$ 近傍の微小領域（面積 $d S$ ） における人口密度（所与）及び施設密度ともにそれぞれ $p(x), n(x)$ と 表せるとする，施設数が十分大きい場合には，微小領域では施設密 度は一様としてよいので, 施設までの平均距離は近似的に

$$
d(x)=k / \sqrt{n(x)}
$$

となる $(k$ は前出).これを用いれば，施設までの平均距離を最小化 する問題は, 総人口を

$$
P=\int_{D} p(x) d S
$$

として

$$
\begin{aligned}
\min _{n(x)} \vec{d}[n(x)] & =\frac{1}{P} \int_{D} d(x) p(x) d S \\
& =\frac{k}{P} \sum_{i} \int_{D_{i}} \frac{p(x)}{\sqrt{n(x)}} d S,
\end{aligned}
$$




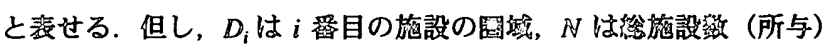

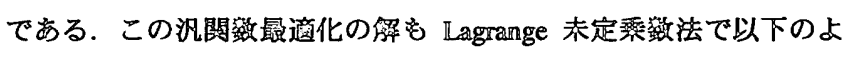
うに解くことができる. Lagrangean を

$$
\mathbb{L}[n(x)]=\int_{D}\left\{\frac{k p(x)}{\mathbb{P} \sqrt{n(x)}}+\lambda n(x)\right\} d S
$$

とすると, 停留䇣件は

$$
-\frac{k}{2 P} \frac{p(x)}{\{n(x)\}^{2 / 3}}+\lambda=0
$$

となるので，䦗理すると

$$
n(x)=\mathbb{C}\{p(x)\}^{2 / 3}
$$

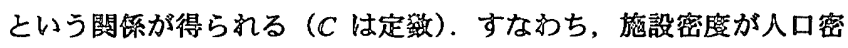

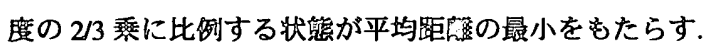

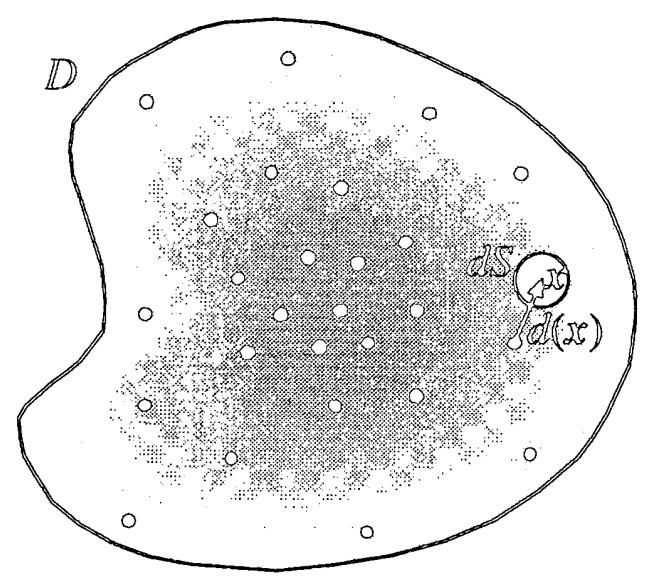

圈 3 運䌇モテル

こうした関係は，施設密度とその平方根の逆臸の和を最小化する という(11)式の形から算かれ，栗田(1996) ${ }^{14)}$ の最適施設缷户笠原・古

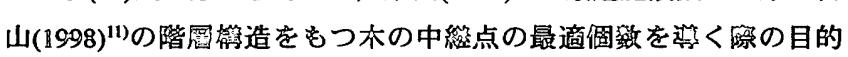

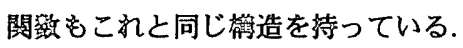

但し，哭際の施設利用では，利用頙度が距注に俍存していたり， 移的の距蹬抵抗が距的に比例しないなど，(1)での前徥が成り立たな い場合には， $\alpha$ は $2 / 3$ という值からは外れる（Palmer (1973) ${ }^{17)}$, Gusein-Zade (1993) $)^{8)}$.

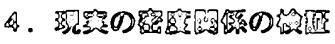

本章では，3章で管いた理諭的関係を，哭際の施設データによっ

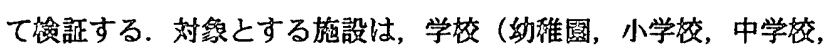

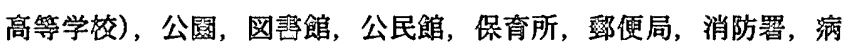

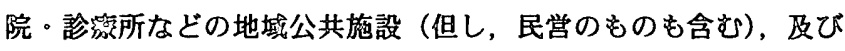

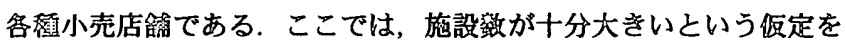
满たすた的，都道府県別に篹計したデータを用いる，地域公共施設

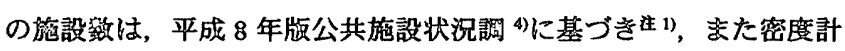

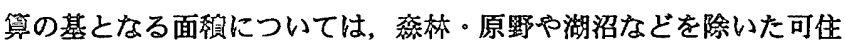

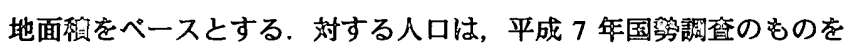
使用する。

3章から望がる一没式

$$
n=C p^{\alpha}
$$

に当てはめ ( $\mathrm{n}$ は简所㥢 $/ \mathrm{km}^{2}, p$ は人/ha), quasi-Newton 法による最

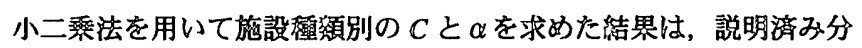
较比の平方根 $\mathbb{R}$ とともに，表 2 のようになった.

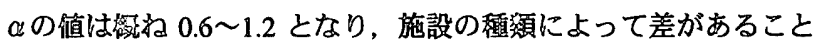
がかかる. 小。中学放, 保育所, 㖶便局などは $2 / 3$ に近い侐となる

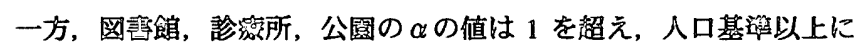
施設が人口の多い地域に偏っている. 初市公園については, 定蛙ら

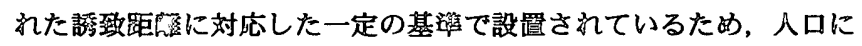

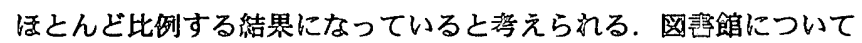
は規償の经佩性や地方部でワンセンターシステムが多いことがこの

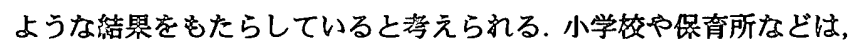

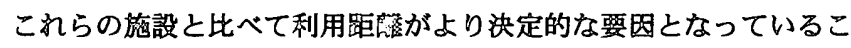

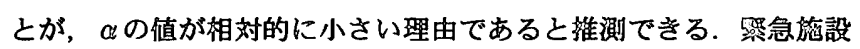
の一つである消防署は， $\alpha$ の值は 0 にはならないまでも，0.62 と小 さい.

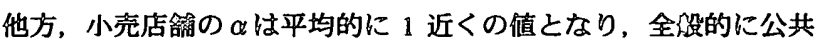

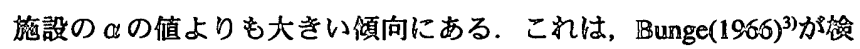
討した中心地理論から算かれる閶係と整合するものである.なお， 診察所や訋推園は民間の占める割合が大きく、病院や保育所等と比 ベて $\propto$ の値が大きいのは, 小売店硧と同溙, 営利性も支配要因とな

\begin{tabular}{|c|c|c|c|c|c|}
\hline 施設慗䫅 & 毁㿽年月日 & $C$ & $\alpha$ & $\mathbb{R}$ & 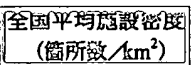 \\
\hline 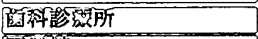 & 06.10 .8 & 0.0166 & 8.328 & 0.981 & 0.657 \\
\hline 国良 & 47.3 .37 & 0.0010 & 7.178 & 0.876 & 0.009 \\
\hline 二熘影酎所 & M6.10.1 & 0.0602 & 0.170 & 0.981 & 0.688 \\
\hline 售肉小无非 & M6.7.8 & 0.0123 & 1.162 & 0.982 & 0.197 \\
\hline 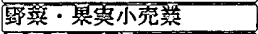 & M6.7.1 & 0.0188 & 1.162 & 0.977 & 0.320 \\
\hline 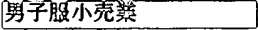 & M6.7.1 & 0.0756 & 0.156 & 0.976 & 0.256 \\
\hline 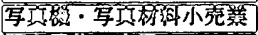 & H6.7. & 0.0056 & 0.910 & 0.952 & 0.092 \\
\hline 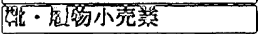 & M6.7.8 & 0.0130 & 0.072 & 0.969 & 0.169 \\
\hline 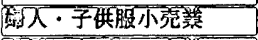 & M6.7.1 & 0.0631 & 0.068 & 0.972 & 0.769 \\
\hline 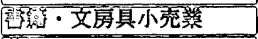 & K6.7.1 & 0.0510 & 0.067 & 0.970 & 0.575 \\
\hline 枀国 & H7.3.31 & 0.0579 & 7.037 & 0.976 & 0.673 \\
\hline 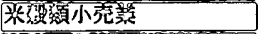 & M6.7.1 & 0.0288 & 9.036 & 0.955 & 0.273 \\
\hline 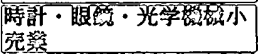 & H6.7.8 & 0.0150 & 0.023 & 0.978 & 0.867 \\
\hline 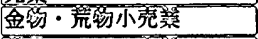 & H6.7.1 & 0.0888 & 1.001 & 0.966 & 0.181 \\
\hline 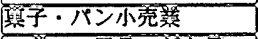 & M6.7.1 & 0.0900 & 0.977 & 0.981 & 0.825 \\
\hline 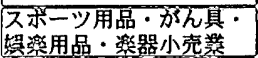 & H6.7.1 & 0.0370 & 0.965 & 0.983 & 0.333 \\
\hline 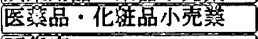 & M6.7.8 & 0.0807 & 0.958 & 0.980 & 0.696 \\
\hline 百樎店 & H6.7.1 & 0.0020 & 0.953 & 0.285 & 0.018 \\
\hline 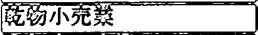 & M6.7.8 & 0.0073 & 0.930 & 0.921 & 0.058 \\
\hline 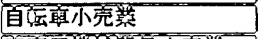 & M6.7.1 & 0.0175 & 0.910 & 0.935 & 0.162 \\
\hline 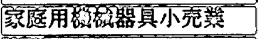 & Y6.7.0 & 0.0788 & 0.873 & 0.976 & 0.562 \\
\hline 敉图 & M7.5.8 & 0.0176 & 0.879 & 0.863 & 0.819 \\
\hline 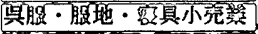 & N6.7.7 & 0.0509 & 0.865 & 0.952 & 0.339 \\
\hline 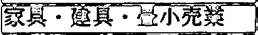 & M6.7.1 & 0.0537 & 0.862 & 0.968 & 0.353 \\
\hline 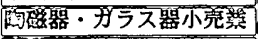 & H6.7.7 & 0.0107 & 0.839 & 0.920 & 0.065 \\
\hline 閶院 & H6.10.0 & 0.0126 & 0.826 & 0.262 & 0.078 \\
\hline 学玟 & M7.5. & 0.0156 & 0.792 & 0.965 & 0.090 \\
\hline 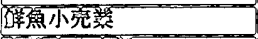 & M6.7. & 0.0535 & 0.769 & 0.922 & 0.279 \\
\hline 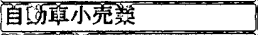 & M6.7.8 & 0.1705 & 0.756 & 0.981 & 0.572 \\
\hline 酒小男器 & N6.7.8 & 0.1519 & 0.769 & 0.951 & 0.738 \\
\hline 高等学 & M7.5.1 & 0.0082 & 0.733 & 0.981 & 0.039 \\
\hline 小学 & M7.5.8 & 0.0886 & 0.669 & 0.959 & 0.096 \\
\hline 察需所 & H6.10.1 & 0.0296 & 0.663 & 0.905 & 0.192 \\
\hline 遑便局 & H7.3.30 & 0.0515 & 0.669 & 0.916 & 0.896 \\
\hline 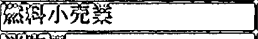 & 66.7. & 0.1576 & 0.626 & 0.982 & 0.576 \\
\hline 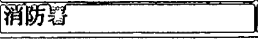 & M7.0. & 0.0037 & 0.617 & 0.928 & 0.013 \\
\hline
\end{tabular}
るためと考えられる.

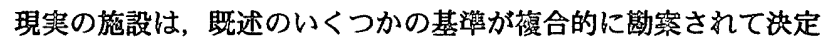

旅設锤別の $\alpha$ 
されており，それぞれの重みは施設種類每に様々であると考えられ る. したがって, どの $\alpha$ が妥当かを論じるのは困難だが， $\alpha$ は今後 の施設整備に関する政策方向を論じる上での一つのマクロ指標とし て有用であると思われる.

また, ここで示した施設密度や人口密度は, 都道府県という集計 単位で計算されたものであるが, 実際には一つの集計単位の中でも 密度が一様でない，集計単位の取り方によって， $\alpha$ の值は変わって くる．この点は実証する上で残された課題である.

\section{5. 結緰と今後の課题}

本論文では, 最近隣施設選択や距離に非弾力的な需要, 距離に比 例する移動コスト等のいくつかの仮定の下で, 移動損失を最小化す る地域施設の望ましい密度が人口密度で決まることを定量的に示し， 以下のことを明らかにした.

(1) 移動損失の最小化の理論から, 施設密度は人口密度の $\alpha$ 乗に比 例するという関係に一般化でき, minimax 基潐, minisum 基準, 人 口基準の場合の $\alpha$ はそれぞれ 0, 2/3,1 となる.

(2) 都道府県別の可住地面積当たりの施設数と人口の関係から上記 の理諭的関係を検証した結果， $\alpha$ は, 小・中学校や保育所, 郵便局 については minisum 基準の $2 / 3$ に近い値となる一方，図書館や診療 所, 公園については 1 を超え, 消防署は小さい値となる. 小売店舖 の $\alpha$ は，その多くが 1 に近い値をとる.

こうした関倸の意味については，4章において解釈を行ったが, より踏み込んだ議論のためにはさらなる施設毎の詳細な検討を要す る. しかし，上記の結覦は，地域施設の設置基準や社会資本投資の 地域配分の再検討, 行政システムの再編に伴う行政区分とその階層 構造の検討などに有用であると考えられる.

なお，施設規模や機能によるサービスの質の違いを全く考虑して いない点や，施設近傍では施設密度が一定という滑らかな分布を前 提としている点, 実証分析における計測方法上の集計問題など, 現 実の施設配置を検討する際には問題となるであろう課題が残されて いる.

筑波大学社会工学系腰塚武志教授及び医名の查読者には貴重なこ 意見を頂いた。ここに記して謝意を表します，なお，本研究は，平 成 10 年度科学研究費補助金（励研究 (A): 課題番号 10780273) による研究の一部である.

注

注 1)但し，病院・一般診療所・菌科診療所については厚生統計要覧平成 7 年版 ${ }^{13)}$, 消防署については平成 7 年版消防白書 ${ }^{21)}$, 郵便局については 平成 6 年度郵政行政統計年報（郵便編） ${ }^{29}$ に依った。

\section{考文献}

1)Beaumont, J.R.: "Location-allocation Models and Central Place Theory," in Ghosh, A. and G. Rushton (eds.): Spatial Analysis and Location-allocation Models, Van Nostrand Reinhold, 21-54, 1987.

2)Beavon, K.S.O.: Central Place Theory: A Reinterpretation, Longman, 1977.

3)Bunge, W.: Theoretical Geography, Lund Studies in Geography, Series C, Number 2, Lund: G.W. Gleenup, 1966.

4)（財）地方財務協会 : 平成 8 年版公共施設状況調, 1997.

5)Dicken, P. and P.E. Lloyd: Location in Space: Theoretical Perspectives in Economic Geography, Third Edition, 1972. （邦訳 伊藤喜栄監訳 : 立地
と空間 一経済地理学の基硅理論一（上・下）, 古今書院）

6)Gusein-Zade, S.M.: "Models of Region Size in a Hierarchical Administrativeterritorial System," Soviet Geography, 22, 599-607, 1982a.

7)Gusein-Zade, S.M.: "Bunge's Problem in Central Place Theory and its Generalizations," Geographical Analysis, 14, 3, 246-258, $1982 \mathrm{~b}$.

8)Gusein-Zade, S.M.: "Alternative Explanations of the Dependence of the Density of Centers on the Density of Population," Journal of Regional Science, 33, 4, 547-558, 1993.

9) 伊理正夫監修 - 腰堟武志䋧 : 計算幾何学と地理情報処理, 共立出版, 1986.

10) Iri, M., Murota, K. and Ohya, T.: "A Fast Voronoi-diagram Algorithm with Applications to Geographical Optimization Problems," in P. ThoftChristensen (ed.) Lecture Notes in Control and Information Science, Vol. 59: System Modelling and Optimization, Proceedings the IFIP Conference on System Modelling and Optimization, Copenhagen, Springer, Berlin, 273-288, 1984.

11)笠原一人・古山正雄 : 「最短木および階層を有する木の長さに関する 考察」, 日本建策学会計画系論文集 第 504 号, 155-161, 1998.

12)柏原士郎 : 地域施設計画論, 鹿島出版会, 1991.

13)厚生省大臣官房統計情報部絽 : 厚生統計要覧 平成 7 年版，(財) 厚 生統計協会, 1996.

14)栗田治 : 「都市施設の数を決めるための数理モテル」, 日本オペレー ションズ・リサーチ学会秋季研究発表会アブストラクト集, 90-91, 1996. 15)中村和郎・高檑伸夫編 : 地理学貄座 1 地理学への招待, 古今書院, 1988.

16)大澤義明 : 「地域施設計画モデルにおける計画施設数と最適眍直及び 最適距部との関係」, 日本建築学会計画系論文集 第 482 号, 165-174, 1996.

17)Palmer, D.S.: "The Placing of Service Points to Minimize Travel," Operational Research Quarterly, 24, 121-123, 1973.

18)Rushton, G.: "Map Transformations of Point Patterns: Central Place Patterns in Areas of Variable Population Density," Regional Science Association Papers, 28, 111-129, 1972.

19)貞広幸雄 : 都市人口分布と店舗分布の比例関係についての考察」, 日本建築学会計画系論文報告集 第 432 号, 99-104, 1992.

20)貞広幸雄 : 「狭域商圈業種の店舗分布と人口分布の関保に関する分析 手法」, 都市計画, 211, 67-72, 1998.

21)消防庁綟: 平成 7 年版 消防白畫, 1995.

22)Stephan, G.E.: "International Tests of the Size-density Hypothesis," American Sociological Review, 37, 365-368, 1972.

23)Stephan, G.E.: "Territorial Division: The Least-time Constraint Behind the Formation of Subnational Boundaries," Science, 196, 523-524, 1977.

24)Stephan, G.E.: "The Distribution of Service Establishments," Journal of Regional Science, 28, 1, 29-40, 1988.

25)Stephan, G.E. and M.L. Eggers: "Bunge's Problem in Central Place Theory and Its Generalizations: A Comment," Geographical Analysis, 17, 3, 257-258, 1985.

26)Stephan, G.E. and D.R. McMullin: "The Historical Distribution of County Seats in the United States: A Review, Critique, and Test of Timeminimization Theory," American Sociological Review, 46, 907-917, 1981.

27)鈴木勉 :「施設の最適な階層檴造に関する考察」, 都市計画論文集, 25, $331-336,1990$.

28)通商産業大臣官房調查統計部：平成 6 年商業統計表 第 2 巻 産業 編 (都道府県表)，1995.

29)郵政省諥務局：平成 6 年度 郵政行政統計年報 郵便編, 1994 . 